\title{
PROTOTIPE E-PARKIR UNTUK MENDUKUNG PENINGKATAN PENDAPATAN ASLI DAERAH (PAD) KOTA PEKALONGAN
}

\author{
Eko Budi Susanto, Sattriedi Wahyu Binabar, M. Reza Maulana \\ Program Studi Teknik Informatika \\ STMIK Widya Pratama Pekalongan \\ Korespondensi: eqo_bs@yahoo.com
}

\begin{abstract}
There are several types of local taxes according to Law number 28 of 2009 one of which is a parking tax which is one type of local taxes from the city tax / district. To optimize and increase local revenue (PAD), professional and transparent parking tax management is required. Parking tax management still has several obstacles, among others: lack of supervision in the field, the existence of irresponsible people who take advantage of that neglect to reap the benefits, parking revenue is not entirely given to the municipal officials. One solution to overcome the leak in the management of parking tax funds is to apply electronic parking or E-Parking, so the process of supervision of all things related to parking can be done well, and have an impact on the increase in local revenue from the parking tax sector.
\end{abstract}

Keywords: Information Systems, E-Parking

ABSTRAK

Ada beberapa jenis pajak daerah sesuai dengan Undang-Undang nomor 28 tahun 2009, salah satunya adalah pajak parkir yang merupakan salah satu jenis pajak daerah dari pajak kota / kabupaten. Untuk mengoptimalkan dan meningkatkan pendapatan asli daerah (PAD) diperlukan pengelolaan pajak parkir yang profesional dan transparan. Pengelolaan pajak parkir masih memiliki beberapa kendala, antara lain: kurangnya pengawasan di lapangan, adanya orang yang tidak bertanggung jawab yang memanfaatkan pengabaian tersebut untuk menuai keuntungan, pendapatan parkir tidak sepenuhnya diberikan kepada pemkot. Salah satu solusi untuk mengatasi kebocoran dalam pengelolaan dana pajak parkir adalah dengan menerapkan parkir elektronik atau E-Parki, sehingga proses pengawasan segala hal yang berkaitan dengan parkir dapat dilakukan dengan baik, dan berdampak pada peningkatan pendapatan asli daerah dari sektor pajak parkir.

Kata Kunci : Sistem Informasi, E-Parkir

\section{Latar Belakang}

Pendapatan Daerah menurut Undang-Undang Nomor 34 Tahun 2004 tentang Perimbangan Keuangan Antara Pusat dan Daerah Pasal 1 angka 18, yang selanjutnya disebut PAD adalah pendapatan yang diperoleh Daerah yang dipungut berdasarkan Peraturan Daerah sesuai dengan peraturan perundang-undangan. Sumber-sumber PAD antara lain Pajak Daerah, Retribusi Daerah, hasil pengelolaan kekayaan daerah yang dipisahkan dan lain-lain PAD yang sah (Republik Indonesia, 2004). Ada beberapa jenis pajak daerah menurut Undang-undang nomor 28 tahun 2009 salah satunya 
adalah pajak parkir yang merupakan salah satu jenis pajak daerah dari pajak kota/kabupaten (Republik Indonesia, 2009).

Pajak Parkir merupakan pemasukan PAD yang diandalkan di Kota Pekalongan, hal ini mengingat Kota Pekalongan memiliki luas wilayah yang paling kecil dibandingkan dengan wilayah Kabupaten disekitarnya. Untuk mengoptimalkan dan meningkatkan PAD diperlukan pengelolaan pajak parkir yang profesional dan transparan.

Menurut Roy Ardiansyah dalam penelitiannya pajak parkir merupakan penyumbang pendapatan terbesar kedua setelah retribusi pasar di Kota Pekalongan. Akan tetapi dalam pengelolalan pajak parkir masih terdapat kendala beberapa diantaranya kurangnya pengawasan di lapangan, sehingga juru parkir tidak melaksanakan tepat waktu pada jam kerja yang sudah ditetapkan, adanya oknum yang tidak bertanggungjawab yang memanfaatkan kelengahan tersebut untuk meraup keuntungan, pendapatan parkir tidak seluruhnya diberikan kepada petugas pemkot dan petugas hanya memberikan karcis yang belum tentu dihabiskan oleh juru parkir (Implementasi Kebijakan Retribusi Parkir Guna Meningkatkan Pendapatan Asli Daerah Kota Pekalongan, 2016).

Solusi untuk mengatasi kebocoran dalam pengelolaan dana pajak parkir adalah dengan menerapkan parkir elektronik atau E-Parkir, sehingga proses pengawasan terhadap semua hal terkait parkir dapat dilakukan dengan baik dan berdampak pada meningkatnya pendapatan asli daerah dari sektor pajak parkir. Selain itu E-parking juga akan memberikan pelayanan yang lebih baik kepada masyarakat di bidang perparkiran

\subsection{Rumusan Masalah}

Kota Pekalongan belum memiliki sistem pengelolaan parkir secara elektronik dan masih dilakukan secara manual dalam pelaporannya, sehingga menimbulkan kerawanan penyelewengan dana pajak parkir. Di sisi lain pajak parkir merupakan pendapatan asli daerah yang cukup penting bagi Kota Pekalongan. Dari uraian diatas maka perumusan masalah yang diangkat adalah bagaimana membangun dan mewujudkan Sistem Parkir elektronik pada Pemerintah Kota Pekalongan

\subsection{Tujuan Penelitian}

Tujuan dari penelitian ini adalah terciptanya sistem parkir elektronik yang diharapkan dapat mengontrol pengelolaan parkir di kota Pekalongan.

\subsection{Manfaat Penelitian}

Adapun manfaat sistem parkir elektronik diantaranya: dapat mengurangi kebocoran dalam penerimaan dana pajak parkir, pengawasan terhadap pengelolaan parkir dapat dilakukan dengan baik.

\section{LANDASAN TEORI}

\subsection{Penelitian Terkait}

Dalam penelitiannya, Roy Ardiyansyah (Implementasi Kebijakan Retribusi Parkir Guna Meningkatkan Pendapatan Asli Daerah Kota Pekalongan, 2016) menganalisa implementasi kebijakan pajak parkir guna mengingkatkan pendapatan asli daerah Kota Pekalongan. Dalam pelaksanaannya, usaha yang dilakukan Dinas terkait untuk mengatasi permasalahan parkir kurang optimal. Hal itu karena masih adanya hambatan yang dialami. Permasalahan salah satunya kurang pantauan dari personil Dinas terkait di lapangan. Kurangnya pantauan tersebut menyebabkan adanya lahan parkir yang berpotensi tidak dikelola melainkan digunakan pedagang kaki lima untuk berjualan. Padahal lahan yang berpotensi tersebut sangat berpegaruh terhadap pendapatan.Selain itu juga 
kurangnya pantauan tersebut menyebabkan juru parkir tidak melaksanakan tepat waktu pada jam kerja yang sudah ditetapkan.

Dalam penelitiannya, Novy Yulianto (Perancangan Sistem Informasi Parkir dengan WiFi Berbasis Arduino, 2016) mengembangkan suatu sistem yang secara otomatis dapat melakukan monitoring untuk memastikan ketersediaan tempat parkir di suatu gedung via web internet. Teknologi otomatisasi yang digunakan adalah menggunakan microcontroller dengan platform Arduino Uno yang berbasis open source. Dengan menggunakan teknologi ini keadaan tempat parkir dapat dengan mudah di monitoring baik jumlah tempat parkir yang tersedia maupun posisi tempat parkir yang masih kosong.

Dalam penelitiannya, Noor Faiz (Pengembangan Sistem Parkir di Universitas Muria Kudus dengan Menggunakan Enkripsi Data dan Teknologi Barcode, 2014) mengembangkan sistem parkir yang berbasis komputerisasi dengan penggunaan teknologi barcode merupakan nilai tambah untuk peningkatan keamanan sebuah sistem parkir. Tujuan dari pembuatan sistem parkir ini adalah menghasilkan suatu sistem parkir yang efisien, handal dan aman dengan memanfaatkan teknologi barcode. Barcode diciptakan dari hasil enkripsi dengan menggunakan metode caesar NIM, NIDN, NIP.

\subsection{Undang-Undang Nomor 34 Tahun 2004}

Menurut Undang-Undang Nomor 34 Tahun 2004, Pendapatan Asli Daerah (PAD) adalah pendapatan yang diperoleh Daerah yang dipungut berdasarkan Peraturan Daerah sesuai dengan peraturan perundang-undangan. PAD bersumber dari Pajak Daerah, Retribusi Daerah, hasil pengelolaan kekayaan Daerah yang dipisahkan, lain-lain PAD yang disahkan.

\subsection{Undang-Undang Nomor 28 Tahun 2009}

Menurut Undang-Undang Nomor 28 Tahun 2009, terdapat dua jenis pajak daerah, yaitu pajak provinsi dan pajak kabupapten/kota. Pajak provinsi meliputi Pajak Kendaraan Bermotor, Bea Balik Nama Kendaraan Bermotor, Pajak Bahan Bakar Kendaraan Bermotor, Pajak Air Permukaan, dan Pajak Rokok.

Sedangkan pajak kabupaten/kota meliputi Pajak Hotel, Pajak Restoran, Pajak Hiburan, Pajak Reklame, Pajak Penerangan Jalan, Pajak Mineral Bukan Logam dan Batuan, Pajak Parkir, Pajak Air Tanah, Pajak Sarang Burung Walet, Pajak Bumi dan Bangunan Perdesaan dan Perkotaan, dan Pajak Perolehan Hak atas Tanah dan Bangungan.

\subsection{Parkir}

Parkiri terdiri dari tiga jenis, yaitu parkir tepi jalan, pakir di luar badan jalan, dan tempat khusus parkir. PAD dari jenis parkir tepi jalan disebut dengan Retribusi Pelayanan Parkir Tepi Jalan Umum, PAD dari jenis parkir di luar badan jalan disebut Pajak Parkir, sedangkan PAD dari tempat khusus parkir disebut dengan retribusi tempat khusus parkir.

Menurut perda Kota Pekalongan Nomor 9 Tahun 2011, Pajak Parkir adalah pajak atas penyelenggaraan tempat parkir di luar badan jalan, baik yang disediakan berkaitan dengan pokok usaha maupun yang disediakan sebagai suatu usaha, termasuk penyediaan tempat penitipan kendaraan bermotor .

Menurut Perda Kota Pekalongan Nomor 1 Tahun 2017, retribusi pelayanan parkir tepi jalan ditujukan bagi kendaraan bermotor yang parkir ditepi jalan dan parkir insidentil. Parkir insidentil diperuntukkan bagi kendaraan bermotor pada saat adanya suatu kegiatan tertentu. 
Menurut Perda Nomor 22 Tahun 2011, Objek Retribusi Tempat Khusus Parkir adalah pelayanan tempat khusus parkir yang disediakan, dimiliki dan/atau dikelola oleh Pemerintah Daerah, meliputi : pelataran/lingkungan parkir, taman parkir, gedung parkir.

\subsection{Sistem Informasi Berbasis WEB}

Sistem informasi dahulu dibuat secara konvensional (aplikasi desktop). Namun seiring dengan perkembangan teknologi internet maka sistem informasi dibuat berbasis web karena sifatnya yang luas dan memungkinkan semua orang dapat mengakses informasi secara cepat dan mudah dari mana saja, sehingga pemasukan data dapat dilakukan dari mana saja dan dapat dikontrol dari satu tempat sebagai sentral.

World Wide Web(WWW) atau yang biasa disingkat dengan web ini merupakan salah satu bentuk layanan yang dapat diakses melalui internet. Web adalah fasilitas hypertext untuk menampilkan data berupa teks, gambar, bunyi, animasi, dan data multimedia lainnya, yang mana data tersebut saling berhubungan satu sama lainnya (Purbo, 2006).

\subsection{Undang-Undang Informasi dan Transaksi Elektronik (UUITE)}

Materi undang-undang informasi dan transaksi elektronik dibagi menjadi dua bagian, bagian pertama mengatur tentang informasi dan transaksi elektronik, bagian kedua mengatur tentang perbuatan yang dilarang (cybercrimes).

Bagian pertama dimaksudkan untuk mengakomodir kebutuhan para pelaku bisnis di internet dan masyarakat umumnya untuk mendapatkan kepastian hukum dalam melakukan transaksi elektronik. Beberapa materi yang diatur, antara lain:

1. Pengakuan informasi/dokumen elektronik sebagai alat bukti hukum yang sah (Pasal 5 \& Pasal 6 UU ITE);

2. Tanda tangan elektronik (Pasal 11 \& Pasal 12 UU ITE)

3. Penyelenggaraan sertifikasi elektronik (certification authority, Pasal 13 \& Pasal 14 UU ITE);

4. Penyelenggaraan sistem elektronik (Pasal 15 \& Pasal 16 UU ITE);

Beberapa materi perbuatan yang dilarang (cybercrimes) yang diatur dalam UU ITE, antara lain:

1. Konten llegal, yang terdiri dari, antara lain: kesusilaan, perjudian, penghinaan/pencemaran nama baik, pengancaman dan pemerasan (Pasal 27, Pasal 28, dan Pasal 29 UU ITE);

2. Akses ilegal (Pasal 30);

3. Intersepsi ilegal (Pasal 31);

4. Gangguan terhadap data (data interference, Pasal 32 UU ITE);

5. Gangguan terhadap sistem (system interference, Pasal 33 UU ITE);

6. Penyalahgunaan alat dan perangkat (misuse of device, Pasal 34 UU ITE)

2.7 Istilah Tentang ITE Berdasarkan UU No. 11 Th. 2008 Tentang Informasi dan Transaksi Elektronik Pasal 1

Informasi Elektronik adalah satu atau sekumpulan data elektronik, tetapi tidak terbatas pada tulisan, suara, gambar, peta, rancangan, foto, electronic data interchange (EDI), surat elektronik (electronic mail), telegram, teleks, telecopy atau sejenisnya, huruf, tanda, angka, Kode Akses, simbol, atau perforasi yang telah diolah yang memiliki arti atau dapat dipahami oleh orang yang mampu memahaminya (Indonesia, 2008).

Transaksi Elektronikadalah perbuatan hukum yang dilakukan dengan menggunakan Komputer, jaringan Komputer, dan/atau media elektronik lainnya. 
Teknologi Informasi adalah suatu teknik untuk mengumpulkan, menyiapkan, menyimpan, memproses, mengumumkan, menganalisis, dan/atau menyebarkan informasi.

Dokumen Elektronik adalah setiap Informasi Elektronik yang dibuat, diteruskan, dikirimkan, diterima, atau disimpan dalam bentuk analog, digital, elektromagnetik, optikal, atau sejenisnya, yang dapat dilihat, ditampilkan, dan/atau didengar melalui Komputer atau Sistem Elektronik, termasuk tetapi tidak terbatas pada tulisan, suara, gambar, peta, rancangan, foto atau sejenisnya, huruf, tanda, angka, Kode Akses, simbol atau perforasi yang memiliki makna atau arti atau dapat dipahami oleh orang yang mampu memahaminya.

\subsection{Sistem Informasi Berbasis Mobile}

Sistem informasi yang dirancang khusus untuk perangkak bergerak (mobile device), agar dapat diakses dimana saja dan kapan saja. Mobile device sendiri pada umumnya dapat diartikan sebagai perangkat yang memiliki ukuran fisik kecil, dapat dioperasikan dimana saja, perangkat bergerak dapat memberikan pelayanan informasi suara dan komunikasi pesan dapat berupa bertukar text maupun gambar. Perangkat mobile dapat mengakses informasi dari jaringan internet dan menampilkan konten dari sistem informasi (Perancangan Sistem Informasi Akademik Berbasis Mobile Web, 2008).

Android merupakan sistem berbasis Linux yang dirancang untuk perangkat seluler layar sentuh seperti telepon pintar dan komputer tablet. Android awalnya dikembangkan oleh Android, Inc., dengan dukungan finansial dari Google, yang kemudian membelinya pada tahun 2005. Sistem operasi ini dirilis secara resmi pada tahun 2007, bersamaan dengan didirikannya Open Handset Alliance, konsorsium dari perusahaan-perusahaan perangkat keras, perangkat lunak, dan telekomunikasi yang bertujuan untuk memajukan standar terbuka perangkat seluler.

Antarmuka pengguna Android didasarkan pada manipulasi langsung, menggunakan masukan sentuh yang serupa dengan tindakan di dunia nyata, seperti menggesek, mengetuk, mencubit, dan membalikkan cubitan untuk memanipulasi obyek di layar.

Android adalah sistem operasi dengan sumber terbuka (open source), dan Google merilis kodenya di bawah Lisensi Apache. Kode dengan sumber terbuka (open source) dan lisensi perizinan pada Android memungkinkan perangkat lunak untuk dimodifikasi secara bebas dan didistribusikan oleh para pembuat perangkat, operator nirkabel, dan pengembang aplikasi. Selain itu, Android memiliki sejumlah besar komunitas pengembang aplikasi (apps) yang memperluas fungsionalitas perangkat, umumnya ditulis dalam versi kustomisasi bahasa pemrograman Java.

\section{PEMBAHASAN}

\subsection{Pengumpulan Data}

Kendala yang dihadapi oleh Dinas Perhubungan Kota Pekalongan terhadap pengelolaan retribusi parkir, yaitu kurangnya pengawasan pengelolaan retribusi parkir, sehingga menyebabkan penerimaan PAD dari sektor parkir menjadi kurang optimal. Terdapat indikasi penyelewengan pelaporan hasil retribusi parkir kepada dinas perhubungan yang dilakukan oleh para juru parkir.

Sedangkan jenis dan besarnya tarif retribusi parkir tercantum dalam perda nomor 9 tahun 2011 tentang pajak parkir, perda nomor 21 tahun 2011 tentang pelayanan parkir tepi jalan, perda nomor 22 tahun 2011 tentang tempat parkir 
khusus, dan perda nomor 1 tahun 2017 tentang perubahan atas peraturan daerah nomor 21 tahun 2011.

Tabel 3. 1 Tarif Retribusi Tepi Jalan

\begin{tabular}{c|c}
\hline Jenis Kendaraan & Tarif Parkir \\
\hline Kendaraan Roda Dua & Rp. 1000 \\
\hline Kendaraan Roda Tiga & Rp. 1000 \\
\hline Kendaraan Roda Empat & Rp. 2000 \\
\hline Kendaraan Roda lebih dari empat & Rp. 15000 \\
\hline
\end{tabular}

Tabel 3. 2 Tarif Retribusi Tempat Parkir Khusus

\begin{tabular}{|c|c|c|c|}
\hline $\begin{array}{c}\text { JENIS } \\
\text { TEMPAT }\end{array}$ & JENIS KENDARAAN & $\begin{array}{c}\text { TARIF SEKALI } \\
\text { PARKIR } \\
\end{array}$ & KETERANGAN \\
\hline $\begin{array}{l}\text { a. Pelataran/ } \\
\text { Lingkungan }\end{array}$ & $\begin{array}{l}\text { sepeda motor } \\
\text { mobil penumpang/mobil } \\
\text { barang } \\
\text { bus sedang/truck sedang } \\
\text { bus besar/truck besar }\end{array}$ & $\begin{array}{l}\text { Rp. } 4.000,- \\
\text { Rp. } 6.000,-\end{array}$ & \multirow{3}{*}{$\begin{array}{l}\text { (1) Ketentuan Struktur dan Besarnya } \\
\text { Tarif : } \\
\text { Berlaku untuk satu kali parkir } \\
\text { maksimum } 2 \text { (dua) jam. } \\
\text { Lebih dari } 2 \text { (dua) jam, tiap } 1 \text { (satu) } \\
\text { jam kelebihan dikenakan tarif } \\
\text { tambahan } 50 \text { dari besarnya } \\
\text { retribusi yang ditetapkan. } \\
\text { Kelebihan jam parkir kurang dari } 1 \\
\text { (satu) jam dihitung } 1 \text { (satu) jam. } \\
\text { (2) Keterangan Jenis Kendaraan : } \\
\text { a. mobil Penumpang, adalah } \\
\text { kendaraan bermotor angkutan } \\
\text { orang yang memiliki tempat } \\
\text { duduk max } 8 \text { orang termasuk } \\
\text { pengemudi atau beratnya tidak } \\
\text { lebih dari } 3.500 \mathrm{~kg} \text {. } \\
\text { mobil barang adalah kendaraan } \\
\text { bermotor angkutan barang yang } \\
\text { beratnya tidak lebih dari } 3.500 \\
\text { kg. } \\
\text { mobil bis sedang, adalah } \\
\text { kendaraan bermotor angkutan } \\
\text { orang yang memiliki tempat } \\
\text { duduk } 9 \text { s/d } 26 \text { orang termasuk } \\
\text { pengemudi atau beratnya tidak } \\
\text { lebih dari } 3.501 \text { kg s/d } 8.000 \mathrm{~kg} \text {. } \\
\text { mobil bis besar adalah } \\
\text { kendaraan bermotor angkutan } \\
\text { orang yang memiliki tempat } \\
\text { duduk lebih dari } 26 \text { orang } \\
\text { termasuk pengemudi atau yang } \\
\text { beratnya lebih dari } 8000 \mathrm{~kg} \text {. }\end{array}$} \\
\hline b. Taman & $\begin{array}{l}\text { sepeda motor } \\
\text { mobil penumpang/mobil } \\
\text { barang } \\
\text { bus sedang/truck sedang } \\
\text { bus besar/truck besar }\end{array}$ & $\begin{array}{l}\text { Rp. } 1.000,- \\
\text { Rp. } 2.000,-\end{array}$ & \\
\hline c. Gedung & $\begin{array}{l}\text { sepeda motor } \\
\text { mobil penumpang/mobil } \\
\text { barang } \\
\text { bus sedang/truck sedang } \\
\text { bus besar/truck besar }\end{array}$ & $\begin{array}{l}\text { Rp. } 2.000,- \\
\text { Rp. } 4.000,-\end{array}$ & \\
\hline
\end{tabular}

\subsection{Alur Bisnis E-ParkirAnalisis Data}

Pada penelitian ini diusulkan alur bisnis e-parkir sebagai berikut:

1. Pembayaran dilakukan dengan cara non-tunai menggunakan smart card. Smart Card dapat dibeli oleh masyarakat di outlet-outlet yang telah ditunjuk oleh Dinas Perhubungan atau melalui juru parkir. Saldo pada Smart Card juga dapat diisi ulang.

2. Juru parkir akan mendatangi masyarakat yang telah selesai memakir kendaraan di tempat parkir untuk melakukan transaksi melalui smart card yang dimiliki masyarakat.

3. Proses transaksi parkir dilakukan dengan cara:

a. Juru pakir memindai barcode yang berada pada smart card

b. Saldo pada smart card akan berkurang

c. Bukti transaksi parkir akan terkirim melalui sms ke handphone masyarakat

4. Dinas Perhubungan dapat melakukan monitoring penelolaan keuangan melalui sistem secara real time. 


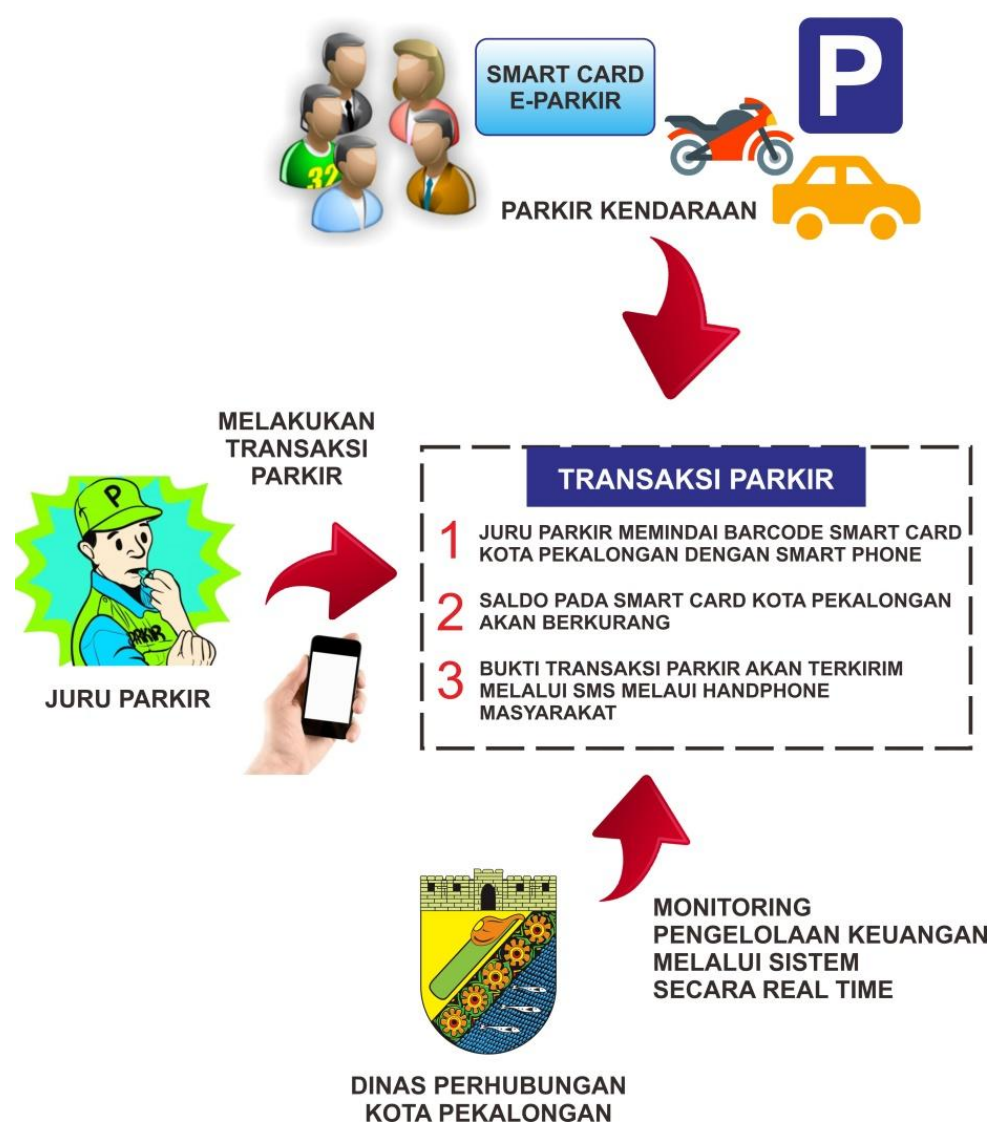

Gambar 3. 1 Alur Bisnis E-Parkir

\subsection{Keunggulan Sistem yang diusulkan}

3.3.1 Keunggulan Sistem Bagi Dinas Perhubungan / Pemerintah Kota Pekalongan

Sistem yang diusulkan memiliki beberapa keunggulan bagi Dinas

Perhubungan, antara lain:

1. Sistem e-parkir mudah untuk dirawat dan dikembangkan

2. Alat pendukung e-parkir mudah didapatkan dengan harga yang relatif murah

3. Penerapan e-parkir tidak menimbulkan gejolak dari juru parkir yang ada, karena keberadaan juru parkir tetap diperlukan

4. Dapat melakukan monitoring semua transaksi parkir secara mudah dan real time

5. Dapat mengetahui keluhan-keluhan dari masyarakat, sehingga dapat melakukan pembenahan yang sesuai

6. Peningkatan PAD kota Pekalongan

3.3.2 Keunggulan Sistem Bagi Masyarakat

Sistem yang diusulkan memiliki beberapa keunggulan bagi masyarakat, antara lain:

1. Smart Card kota Pekalongan mudah didapatkan di berbagai tempat yang ditunjuk oleh Pemerintah Kota Pekalongan

2. Pembayaran biaya parkir dapat dilakukan dengan mudah dan non tunai, sehingga tidak perlu menyediakan uang recehan

3. Pembayaran biaya parkir sesuai dengan ketentuan yang berlaku

4. Kemudahan memeriksa saldo dan mengisi ulang saldo smart card

5. Masyarakat dapat menyampaikan keluhan terhadap layanan parkir yang kurang baik 


\subsubsection{Keunggulan Sistem Bagi Juru Parkir}

Sistem yang diusulkan memiliki beberapa keunggulan bagi juru parkir, antara lain:

1. Keberadaan juru parkir tetap diperlukan

2. Ada pendapatan lain yang dapat diperoleh juru parkir yaitu jika ada:

- Masyarakat yang meminta top up untuk mengisi saldo

- Masyarakat yang membeli smart card

\subsection{Desain Sistem}

3.4.1 Desain Pemakai Sistem

\begin{tabular}{|c|c|c|}
\hline No & Pemakai & Otoritas dalam sistem \\
\hline 1. & $\begin{array}{l}\text { Pemerintah Kota } \\
\text { Pekalongan/Dinas } \\
\text { Perhubungan }\end{array}$ & $\begin{array}{ll}\text { - } & \text { Mengelola user/pemakai sistem seperti (juru } \\
& \text { parkir, pengguna parkir/masyarakat, Outlet } \\
& \text { Penjual Smart Card) } \\
\text { - } & \text { Mengelola Tarif Parkir dan Tempat Parkir } \\
\text { - } & \text { Mengelola Transaksi Parkir } \\
\text { - } & \text { Mengelola Top Up Saldo } \\
\text { - } & \text { Mengelola Kotak Saran }\end{array}$ \\
\hline 2. & Petugas Parkir & $\begin{array}{ll}\text { - } & \text { Mengelola Transaksi Parkir } \\
\text { - } & \text { Mengelola Top Up Saldo dan Registrasi Smart } \\
& \text { Card } \\
\text { - } & \text { Mengelola Profil }\end{array}$ \\
\hline 3. & Pengguna & $\begin{array}{ll}\text { - } & \text { Mengelola Profil } \\
\text { - } & \text { Mengelola Saldo } \\
\text { - } & \text { Mengelola History Parkir }\end{array}$ \\
\hline 4. & $\begin{array}{l}\text { Outlet Penyedia } \\
\text { Smart Card }\end{array}$ & $\begin{array}{l}\text { - Mengelola penjualan dan registrasi Smart } \\
\text { Card }\end{array}$ \\
\hline
\end{tabular}

3.4.2 Desain Relasi Tabel dari Sistem

Berikut adalah desain relasi tabel yang akan digunakan pada sistem. 


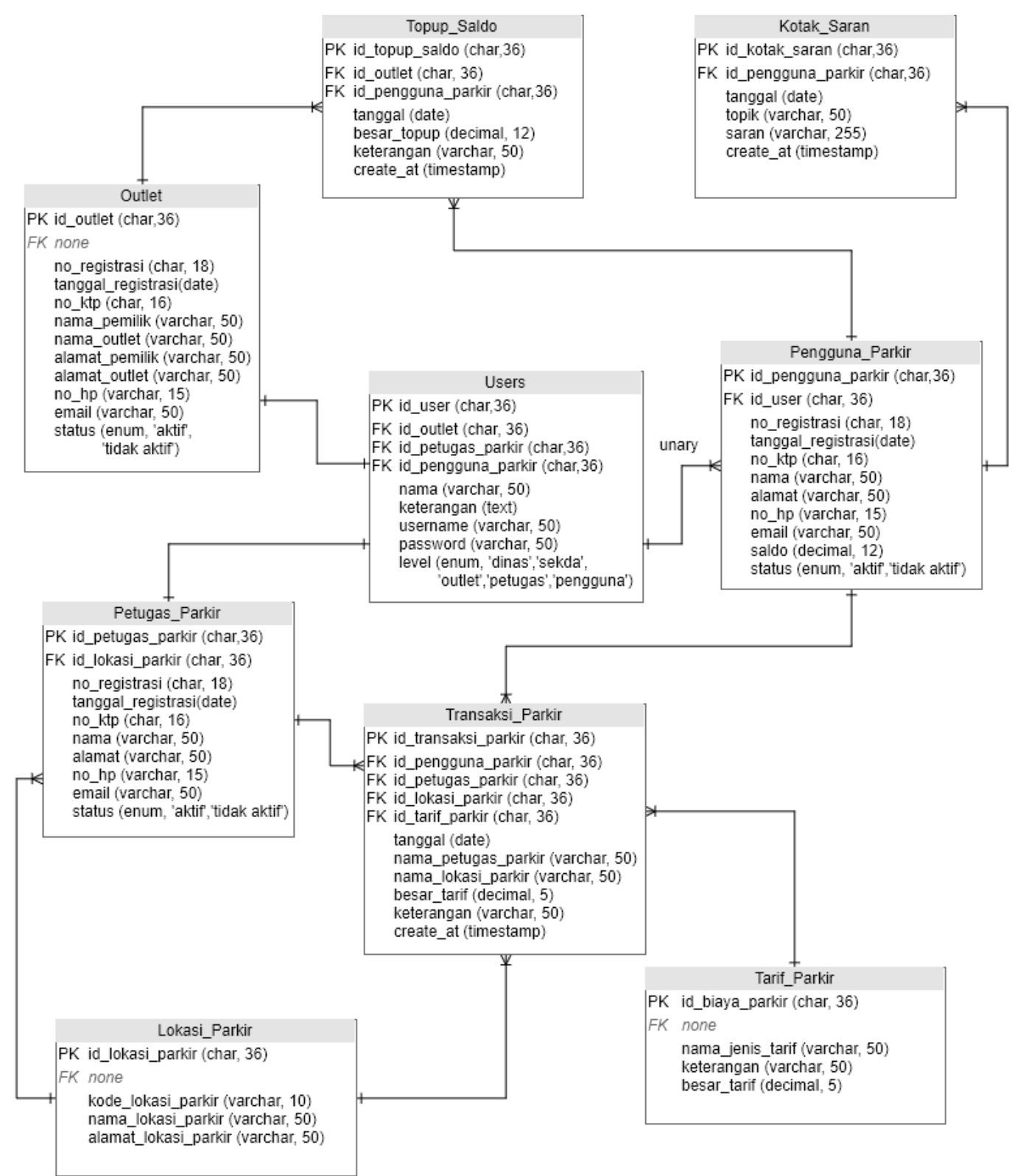

Gambar 3-1 Relasi Tabel 


\subsection{Bentuk Prototipe Sistem}

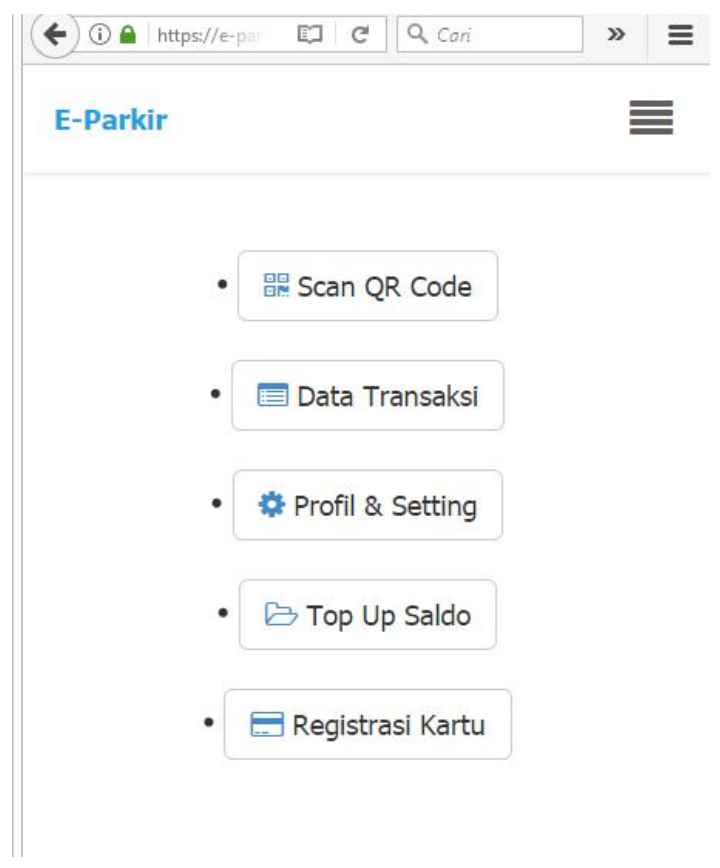

Gambar 3. 2 Halaman Petugas Parkir

E-Parkir

\section{Scan QR Code}

Cek Hasil

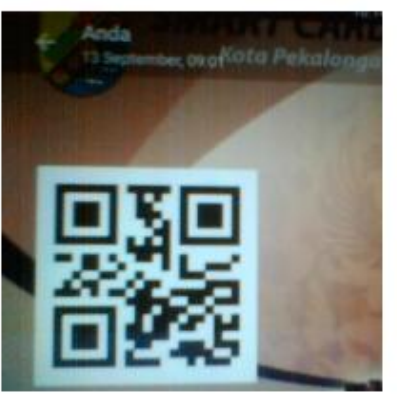

Gambar 3. 3 Halaman Scan QR Code 


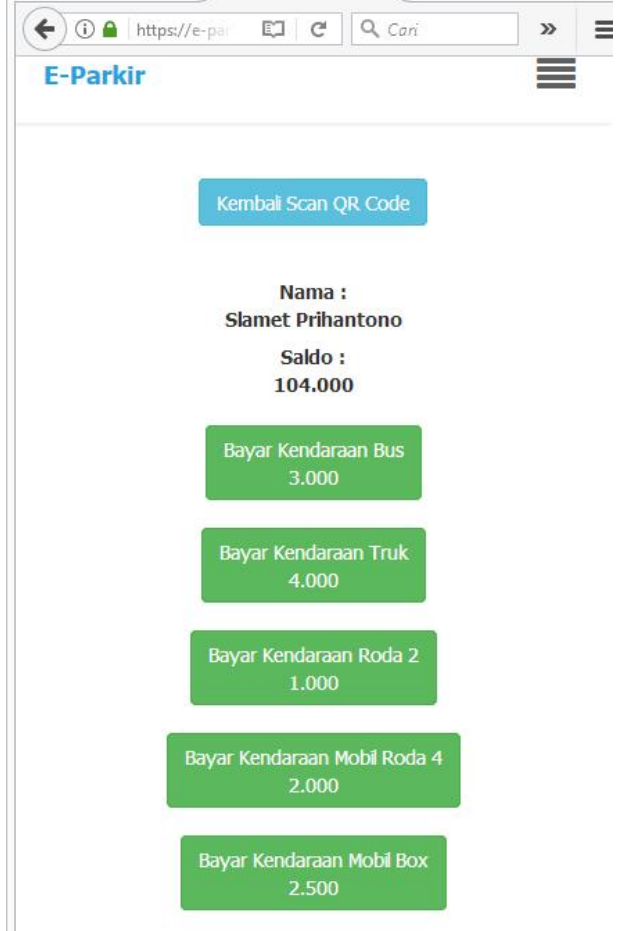

Gambar 3. 4 Halaman Transaksi Tarif Parkir

\begin{tabular}{|c|c|c|c|c|}
\hline \multicolumn{2}{|c|}{ E-Parkir } & $\approx$ REFRESH & * MENU UTAMA & $\rightarrow$ LOGOUT \\
\hline \multicolumn{5}{|c|}{ Data Transaksi Parkir Anda } \\
\hline \multicolumn{5}{|l|}{ Dari } \\
\hline \multicolumn{5}{|l|}{ Sampai } \\
\hline \multicolumn{5}{|c|}{ Fiter } \\
\hline \multicolumn{5}{|c|}{ Periode : 04-09-2017 - 04-10-2017 } \\
\hline & & & Nominal & \\
\hline 1 & 17-09-2017 & & & 2.000 \\
\hline 2 & 17-09-2017 & & & 4.000 \\
\hline 3 & 17-09-2017 & & & 2.000 \\
\hline 4 & 17-09-2017 & & & 3.000 \\
\hline 5 & 17-09-2017 & & & 3.000 \\
\hline 6 & 17-09-2017 & & & 1.000 \\
\hline
\end{tabular}

Gambar 3. 5 Halaman Data Transaksi Petugas Parkir

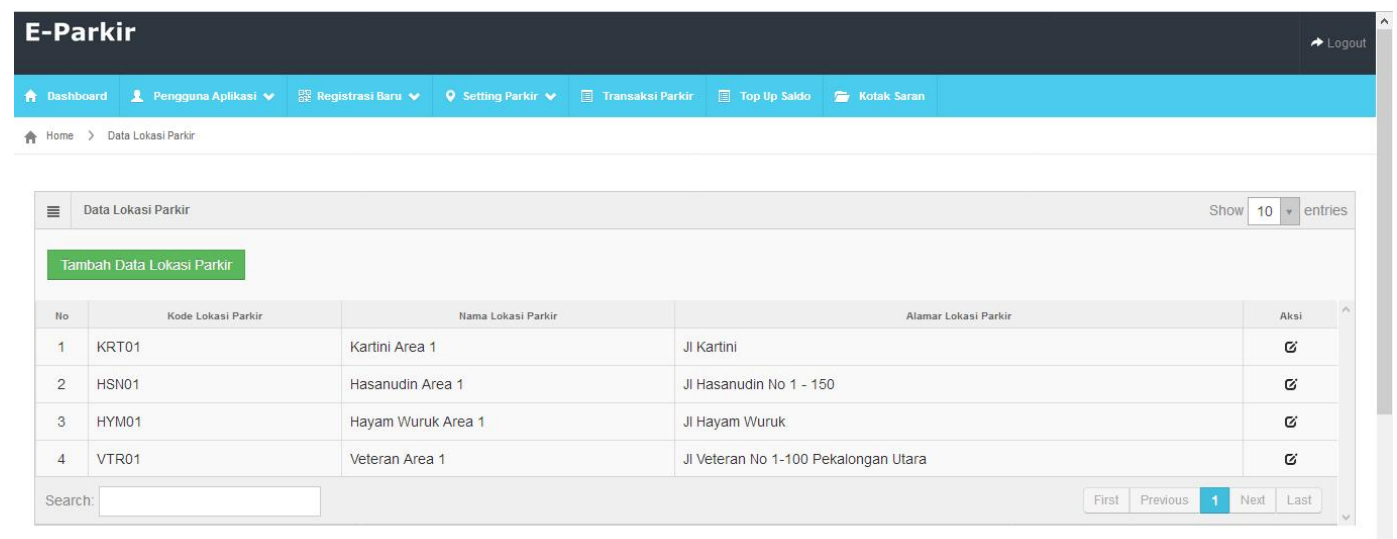

Gambar 3. 6 Data Lokasi Parkir Pada Administrator 


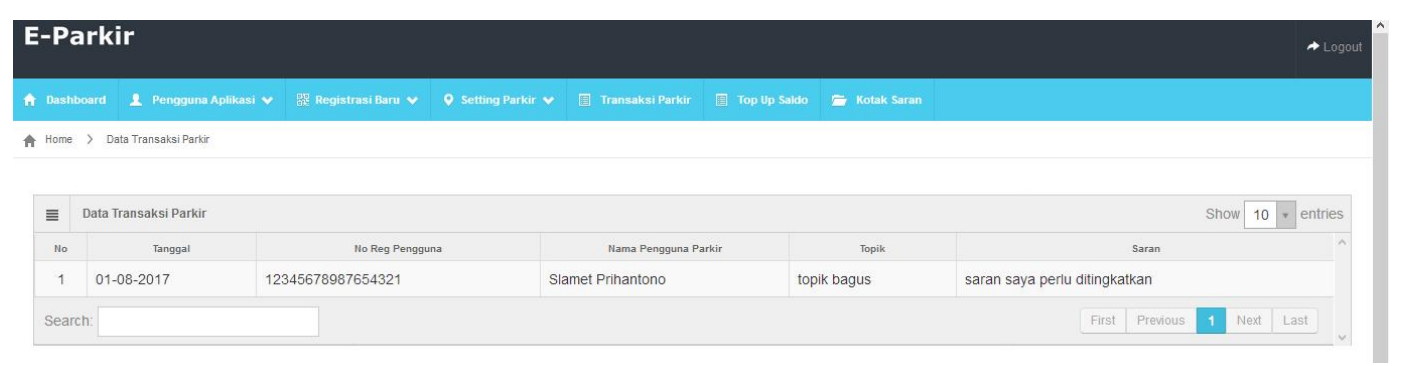

Gambar 3. 7 Data Transaksi Parkir Pada Administrator

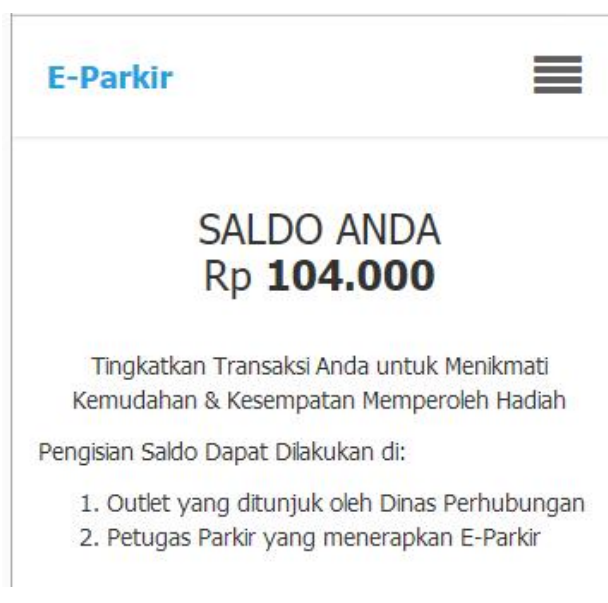

Gambar 3. 8 Halaman Saldo Pada Pengguna/Masyarakat Umum

\section{PENUTUP}

\subsection{Kesimpulan}

Sistem E-Parkir yang diusulkan dapat mengelola pengelolaan dana retribusi parkir. Melalui sistem ini Pemkot Pekalongan atau Dinas Perhubungan Kota Pekalongan dapat melakukan monitoring semua transaksi parkir secara mudah dan real time. Sistem e-parkir mudah untuk dirawat dan dikembangkan, selain itu alat pendukung e-parkir mudah didapatkan dengan harga yang relatif murah.

Pelibatan juru parkir dalam penerapan e-parkir diharapkan tidak menimbulkan gejolak dari juru parkir yang ada, karena keberadaan juru parkir tetap diperlukan.

Pemkot Pekalongan atau Dinas Perhubungan Kota Pekalongan dapat mengetahui keluhan-keluhan dari masyarakat, sehingga dapat melakukan pembenahan yang sesuai.

\subsection{Saran}

Memperhatikan manfaat yang akan diperoleh dari penerapan e-parkir tersebut, maka peneliti memberikan beberapa saran:

1. Mengembangkan prototype menjadi sistem yang benar-benar siap pakai

2. Mempersiapkan beberapa pendukung agar sistem e-parkir dapat berjalan baik

3. Melakukan sosialisasi dari awal untuk meminimalkan adanya kesalahpahaman dari pihak-pihak terkait

Mengintegrasikan dengan sistem yang lain sehingga "Smart Card Kota Pekalongan" dapat berfungsi optimal dan memberikan dampak terhadap peningkatan Pendapatan Asli Daerah. 


\section{DAFTAR PUSTAKA}

Implementasi Kebijakan Retribusi Parkir Guna Meningkatkan Pendapatan Asli Daerah Kota Pekalongan. Ardiansyah, Roy, Sundarso and Yuniningsih, Tri. 2016. 2016, Journal Of Public Policy and Management Review Volume 5 Nomor 2.

Indonesia, Republik. 2008. Undang-Undang Informasi dan Transaksi Elektronik. Jakarta : Sekretariat Negara, 2008.

Pemerintah Kota Pekalongan. 2017. Perda Nomor 1 Tahun 2017, Tentang Perubahan Atas Peraturan Daerah Nomor 21 Tahun 2017 Tentang Pelayanan Parkir Tepi Jalan Umum. Pekalongan : Kota Pekalongan, 2017.

- 2011. Perda Nomor 22 Tahun 2011 Tentang Retribusi Tempat Parkir Khusus. Pekalongan : Pemerintah Kota Pekalongan, 2011.

- 2011. Perda Nomor 9 Tahun 2011 Tentang Pajak Parkir. Kota Pekalongan: Pemerintah Kota Pekalongan, 2011.

Pengembangan Sistem Parkir di Universitas Muria Kudus dengan Menggunakan Enkripsi Data dan Teknologi Barcode. Fais, Muhammad Noor, Susanto, Arief and Listyorini, Tri. 2014. 2014, Jurnal SIMETRIS, Vol 5 No 2 Nopember 2014.

Perancangan Sistem Informasi Akademik Berbasis Mobile Web. Mujab, Syariful, Satoto,

Kodrat Iman and Martono, Kurniawan Teguh. 2008. 2008, Program Studi Sistem Komputer, Fakultas Teknik, Universitas Diponegoro.

Perancangan Sistem Informasi Parkir dengan WiFi Berbasis Arduino. Yulianto, Novi and Bacharuddin, Fahraini. 2016. 2016, LONTAR KOMPUTER VOL. 7, NO.3, DESEMBER 2016.

Purbo, Ono W. 2006. Buku Pegangan Internet Wireless dan Hotspot. Jakarta : PT. Elex Media Komputindo, 2006.

Republik Indonesia. 2009. Undang Undang Nomor 28 Tahun 2009 Tentang Pajak Daerah dan Retribusi Daerah. Jakarta : Sekretariat Negara, 2009.

- 2004. Undang Undang Nomor 34 Tentang Perimbangan Keuangan Antara Pusat dan Daerah. Jakarta : Sekretariat Negara, 2004. 